\title{
The informal economy in Ecuador
}

\section{La economía informal en el Ecuador}

Santiago Francisco Carranco Paredes

Universidad Internacional del Ecuador, Ecuador

Autor para correspondencia: scarrancoparedes@gmail.com

Fecha de recepción: 1 de Julio de 2018 - Fecha de aceptación: 10 de Septiembre de 2018

\section{Resumen}

Este trabajo analizó los efectos de los cambios en los paradigmas económicos que el gobierno de Correa introdujo en las instituciones ecuatorianas, centrándose en las secuelas que dejaron en la economía informal y en la tasa de desempleo. Este trabajo se plantea como objetivo el discutir la manera en la que esta serie de reformas a las políticas económicas del ha contribuido al desarrollo del país y analizar la sostenibilidad de las políticas mencionadas para contribuir a la comprensión sobre la informalidad en el comercio de una perspectiva no occidental, en este caso utilizando como ejemplo el caso de Ecuador.

Palabras clave: economía; Informal economía; Ecuador; América Latina

\begin{abstract}
This paper will analyse the effects of the economic changes that Correa's government introduced on Ecuadorian policies, mainly focussing on the consequence that this policy had on the informal sector and unemployment. There aims of this work is to discuss how this modification to the economical policies have contributed to the development of the country and analyse the sustainability of the mentioned policies in order to contribute to the understanding about the informal economy from a non-western perspective, in this case using as an example the case of Ecuador.
\end{abstract}

Key Words: economy; informal economy; Ecuador; Latin America 


\section{Introduction}

The informal sector was a term coined by Keith Hart (1973), in his papper called Informal Income Opportunities and Urban Employment in Ghana. In this article, Hart refered as an informal to all the profitable activities outside from the traditional taxable markets. Since then, a wide range of similar terms have been used in the literature about the topic, such as hidden economy, black markets, parallel economy and the list continue, Alejandro Portes (1989), defined the informal economy as a process of income-generation that it is not regulated by the institutions of society, when other similar activities are regulated in a legal and social environment. For other authors as Lubel (1993) the informality is a barrer that prevents countries from development and modernization

For the International Labour Organization, the informal economy is associated whit poverty and poor labour conditions as the lack of protection to workers, overtime and extra shifts, unsafe working conditions and the absence of social benefits such as pensions, sick pay and health insurance. However authors like Robert Neuwirth (2012) and Schneider \& Klinglmair(2004), have intended to changed the perception of the meaning of informal economy, by arguing first that informal economies are able to satisfy demands that the formal sector are not, second proving by specifical cases that this sector provide more job opportunities than the traditional sectors of the economy and third that are cases the informal workers have better conditions than salaried ones.

Nowadays, there still debates about how to define the informal sector, in addition to the several discussions about the beneficial and the prejudicial effects that it has on the economy of the states, nevertheless, all the authors will agree that this 'hidden' sector of the economy is massive and bring concerns to all the statesman around the globe. In Latin America, the informality in the commerce and the tax evasion represents a complex issue.

The FORLAC is a regional program from the ILO concerned about the transition of informal workers into the formal sector, in their annual inform of 2013 they set that informality in Latin America has several causes, like the lack of employment, the migration from rural to urban areas and the difficulties that the women had in the inclusion into the formal economies. Besides the fact that people are more concerned about to get income, independently if it comes from a formal or informal sector. Some countries of the region have developed projects that encourage informal workers to reinsert into the formality, like the $\mathrm{RIF}^{1}$ in Mexico in other cases like Ecuador the government have been working since 2007 in structural modifications in the economic policies to fight against the informality.

\section{Case of Study: Correa Revolution and its effect on the Informal Sector.}

In 2006, Ecuador was struggling against a profound political and economic crisis mainly attributable to the administrative instability of the state, in a period of ten years, this state had seven different leaders occupying the charge of president. In addition, a financial crisis in 1999 produced by a collapse of the private banking sector resulted in a dollarization process which let

\footnotetext{
${ }^{1}$ RIF (Regimen de Inserción Fiscal) Is a program that the Mexican government launched in 2013 to regulate the small business in the urban areas of Mexico. (Flores, 2014)
} 
the country in a very sensitive position. By 2007, the Ecuadorians, elected Rafael Correa as their president, a populist university lecturer instructed in economics. Correa was an outsider in the terms of politics, for that reason he wins popularity among the people that was tired of the traditional populist representatives (Jaramillo-Jassir, 2012, pp. 151-152). He comes whit the idea of stabilizing the country and generate development mainly by perform modifications in the economic structure of the state, which they called 'changes in the productive matrix'. In 2007, once elected, the new administration started its revolutionary process which tended to substitute the neoliberal regime stablished in Ecuador since the $80 \mathrm{~s}$, by a model of endogenous growth primarily favouring to the working class. In order to legitimate their actions in the political and in the legal field, a referendum, mainly whit the aim to create a new constitution that included all this reforms was proposed, the result was overwhelming, due to it was approved by the $80 \%$ of the electorate, besides the new constitution that propose a more equalitarian and socialist system, it was accepted by $65 \%$ of the voters. (Becker, 2011, pp. 49-51).

\section{Nationalization of oil companies}

Since the 80s, the main income of the country has come from the oil exportations, however, before 2008, Ecuador was not receiving the maximum utility from it, due to 53, 7\% of the production belongs to the private companies (Indicadores Macroeconómicos, 2012), besides the type of contract that the state maintained whit this corporation was not profitable at all, attributable to the favourable terms for the companies, Ecuador perceived the major income from renting the land rather than from the oil production. In 2010, a project of nationalization and renegotiation of this contracts started. By 2012, the private production of oil where reduced to $25,6 \%$, besides, the remaining companies had to pay $25 \%$ of their total profit to the state (Indicadores Macroeconómicos, 2012), in addition to ecological and profit sharing taxes. By 2012, the activities of companies like Texaco-Chevron and OXY were passed to the national oil company of Ecuador (Petroecuador). This new perception of income played a fundamental role for the future economic reforms.

\section{First reforms to the labour code}

The new constitution of Ecuador prohibited any type of outsourcing and hour paid activities. Obliging the private companies to provide full-time contracts whit fully remunerated salaries. Besides to social healthcare and $15 \%$ of the profit sharing to the workers. By that time in Ecuador 800000 workers were part of outsourcing companies, this represented the $17 \%$ of the labour force. Also, this law included workers involved in the domestic labour. As a result, thousands of workers where involved in the formal sector, which growth from 38, \% from 2009 to $45 \%$ in 2010 (Banco Central del Ecuador, 2014). The workers indeed were satisfied whit this measures, however, a considerable downsizing started in the private sector, because they alleged that was unprofitable to maintain the workers whit this benefits, this was reflected in the unemployment figures that growth from 7, 9\% in 2009 to 9, 1\% in 2010 (Banco Central del Ecuador, 2014), (Uquillas, 2007).

To fight against the rise of unemployment numbers, the government generated jobs by creating new state entities, 6 new national ministries besides a considerable number of regional secretaries and regulatory entities were creates, producing 110000 new jobs since 2008 to 2014 
mainly in the public sector. (Zeas, 2014). In addition, in this last 7 years the minimum wage has growth $100 \%$, in 2007 it was 170 USD, and in 2014 is 340 USD. The critiques that the government have received are based on the lack of production of wealth of the public sector and the enormous cost that represent to maintain it. (Zeas, 2014)

Since the tax evasion have represented a deep concern, the government implemented in 2008 a plan for regulate the small and medium commerce activities and the so called informal economies. The project was called RISE, which is a system in which facilitate the tax payment to the informal workers, besides of receiving a tax discount from 5\% to 50\% depending of their situation. Some of the benefits of the program are that offers a simplified annual payment that facilitate the contributors to pay their taxes. The measure was not well accepted in their beginnings, due to the people in the informal sectors have never paid taxes. However, since its creation, 26000 people have accepted it and now have become part of the formal sector in Ecuador. This measure had mainly the purpose to create a tax education on the informality. In addition, it encourages the employers to offer better working conditions for their workers, because they receive a tax discount for each hand that they employ (Serrano, 2012). The result of the fiscal policy and the insertion of new workers to the formal economy have risen the tax collection in 143\% from 2008 to 2012. Providing in this way more resources to the state to maintain the system.

\section{The Results of the New Taxation Policy}

In the following graphs is possible to device not only that the unemployment rate has fell, but also that the employment in formal sectors has growth, mean the jobs in the informal sector have decreased. This tell us that more workers are able to receive better work conditions, fully paid salaries and social benefits. Besides the rise of the formality means more tax revenue for the state, as the further chart will show. However, most of the employment is due to the risen in the public sector, in 2013, 20.68\% of the formal employment were bureaucrats that do not produce revenue (Inec, 2014), which also means more expenditure for the state. Nevertheless, the growth in Ecuador has been consistently in the last decade, but mainly attributable to the high oil price.

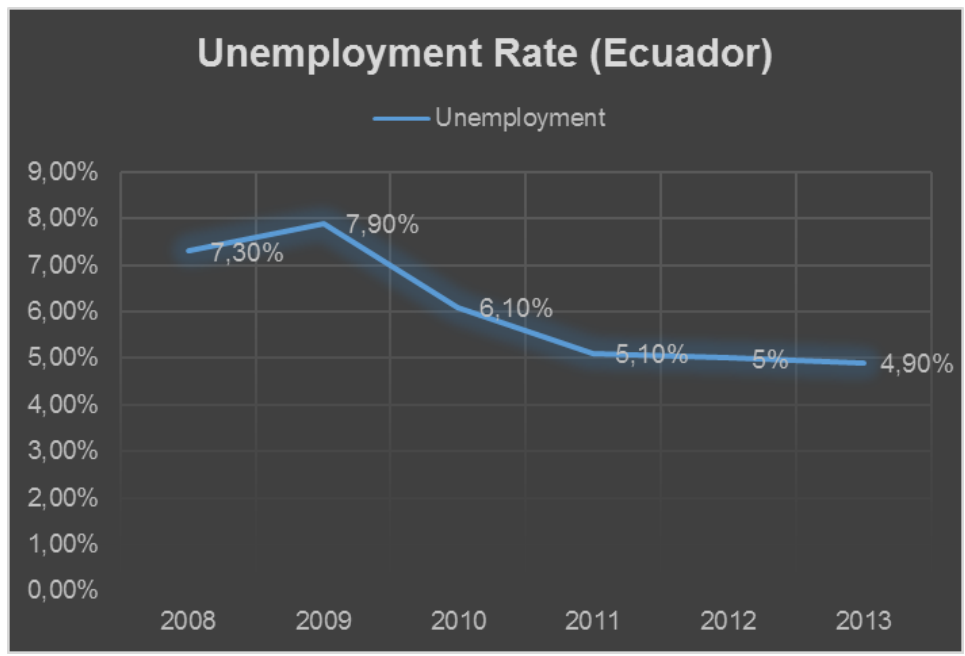

Figure 1: Unemployment rate in Ecuador (2008-2014)

Data Collected from INEC (the governmental department of statistics in Ecuador) 


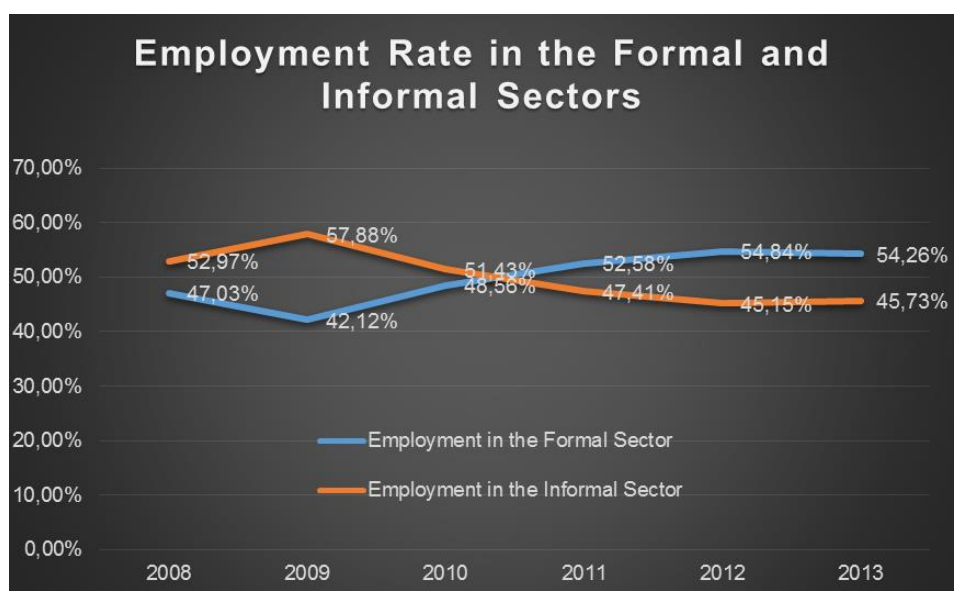

Figure 2: Employment Rate in the Formal and Informal Sectors in Ecuador Data Collected from INEC (the governmental department of statistics in Ecuador)

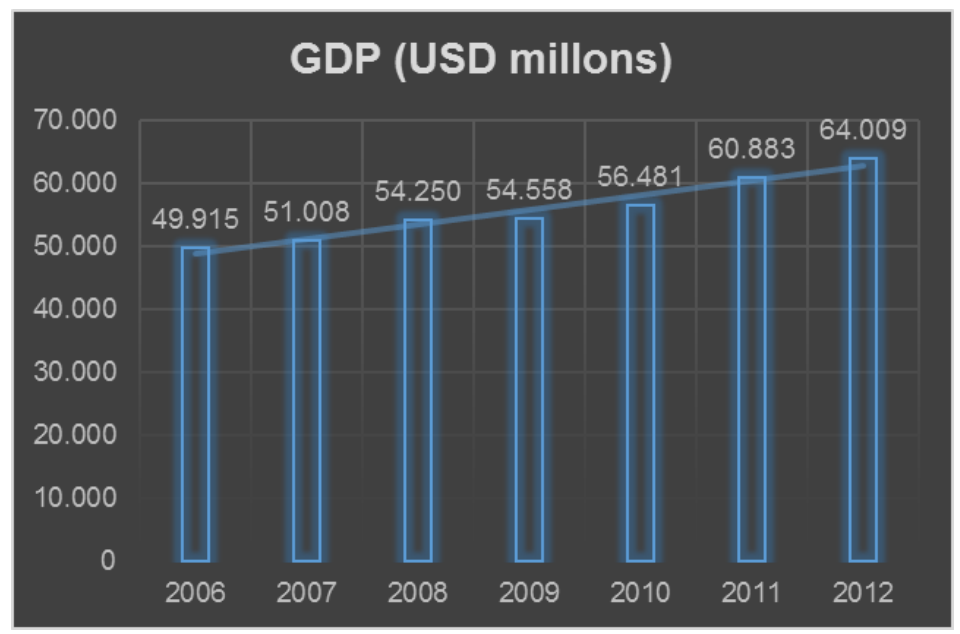

Figure 3: GDP Variation in Ecuador

Data Collected from INEC (the governmental department of statistics in Ecuador)

\section{The real cost to formalize the economy}

As it was possible to device in the previous part of the paper, the Ecuador economy have seen a growth in the GDP and a fall in the unemployment, and in the informal jobs. However, the cost for this success has been very high, first a risen in the public and in the external debt, furthermore, a huge increment in the public sector that could only be maintained by the high price of the oil and the boost of taxes specially for the private sector workers. If is true that the labour conditions of many Ecuadorians have favourably improved, the workers in the private sectors and the so called middle class has been affected by the measures stablished to finance these changes. Besides the fact that the resources of the country are been used to pay salaries in the public sector rather than to incentive the industrial development, which could bring more employment and growth for the economy. In fact, this system seems to not be sustainable in mid and long terms. 


\section{Growth of the public and external debt}

Since 2008, the diplomatic relation between Ecuador and China has been strengthened, it could be reflected in the commercial relations, in 2009, Ecuador signed the $1^{\text {st }}$ of the 5 contracts series of anticipate sales of oil to China, so the government could receive instant income by utilizing the future production. Nowadays, the $60 \%$ for the oil production in Ecuador is already sold to the Eastern giant, and the contracts will finish by 2016, however there are the possibility to renegotiate them. (Pallares, 2012)

\begin{tabular}{|c|c|c|}
\hline Contract & Income Received & Future production sold \\
\hline $1^{\text {st }}$ contract (2009) & 1000 USD millions & 2.88 million of barrels \\
\hline $2^{\text {nd }}$ contract (2010) & 1000 USD millions & 1.08 million of barrels \\
\hline $3^{\text {rd }}$ contract $(2011)$ & 1000 USD millions & 2.88 million of barrels \\
\hline $4^{\text {th }}$ contract $(2011)$ & 2000 USD millions & 1.8 million of barrels \\
\hline $5^{\text {th }}$ contract & NA & $\mathrm{NA}^{2}$ \\
\hline
\end{tabular}

Figure 4: Table of the anticipated sales of oil from Ecuador to China

Furthermore, Ecuador have borrow money from the Asian government creating a debt of 4000 USD millions for Ecuador which growth its external debt by $47.06 \%$ in the period between 2009 and 2013. In addition, the government is studying the possibility to add 7000 USD millions to its balance whit China, with the intention of compensate the fiscal deficit. (Constante, 2014). Additionally, in 2012, the central government lend 1.338,3 USD millions from the IESS (Ecuadorian social security organism) which means an increment of 27, 5\% in the internal debt. The cost of redesign the economic policies in a country has it cost, this numbers are the reflection of the price of the modifications in Ecuadorian system.

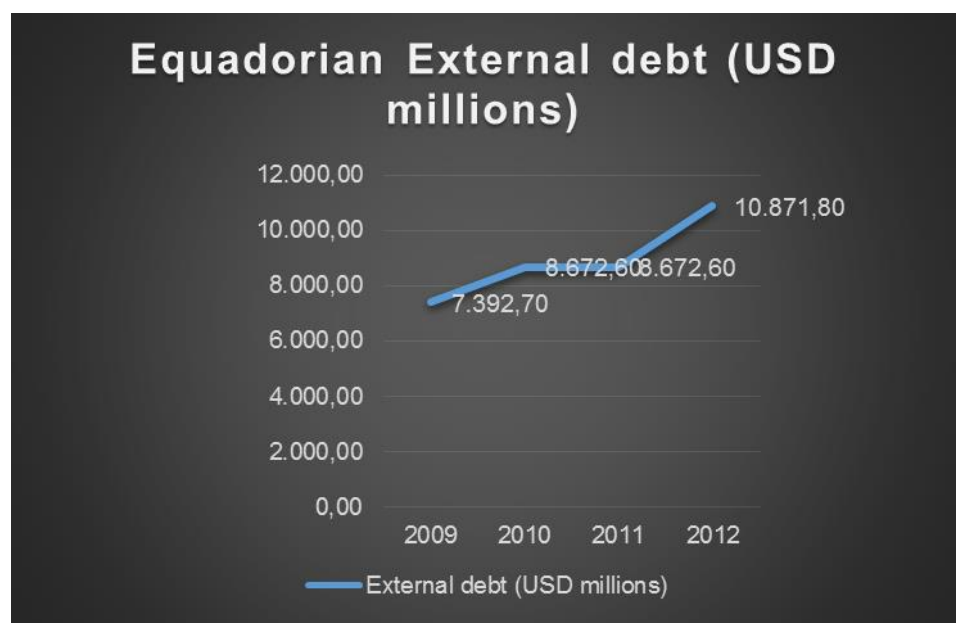

Figure 5: Equadorian External debt (USD millions)

\footnotetext{
${ }^{2}$ There is the possibility to renegotiate the contracts
} 


\section{Taxation and new reforms to the labour code}

Since 2007, the government have risen the tax burden from 14, 4\% to $19,7 \%$ whit the aim to enhance the tax collection and generate major income to the state (Serrano, 2012). In order to be able to maintain the jobs in the public sectors, the government have found a way to increase their income by implementing 51 new taxes since 2008, especially for imported products. The problem is that enormous quantity of consumer products are imported. Creating a second issue which is that the Ecuadorian industry is not developed enough to compensate the consumers demand, or to provide the same quality of imported goods. As consequence, the people finish paying the double of the original cost of a good, providing founds to the government to maintain their public workers.

In addition to the taxation in consumer goods, the new reforms to the labour code have a creating a system in which the private sector workers have the obligation to maintain the public workers. The first reform in the code is to unify the shares of the companies that belongs to the same corporations, this means that the figure of company now is the sum of all the economic activities that belongs to the same owner or group of owners. Making the workers to be part of the whole corporation rather than to a singular company. And second, that the shares of all the corporation will be redistributed to all the workers independently to which singular company they belong. The main problem is that there is a limit to the share that each worker could receive for each year, mean the rest gone to the state revenue.

\section{Migration to Urban Areas}

With the growth of wealth concentration in urban areas, the rural individuals had abandoned their lands and agricultural activities whit the false promise of get a job in the formal sector in the cities. The structural changes have brought growth in the urban places, however it has forgotten about the development in the countryside. (Floro \& Bali, 2013). When this people arrive to the major cities in Ecuador, they seen better opportunities in the informal sector rather than in the formality. Engaging themselves in self-employment activities consisted mainly in umbrella and food stands outside from the government institutions and commerce of replica goods in the streets. As the wages have risen in this place, the informal economies provide products that the formal sector needs, creating in this way a whole new industry in the Ecuadorian informal economy. 

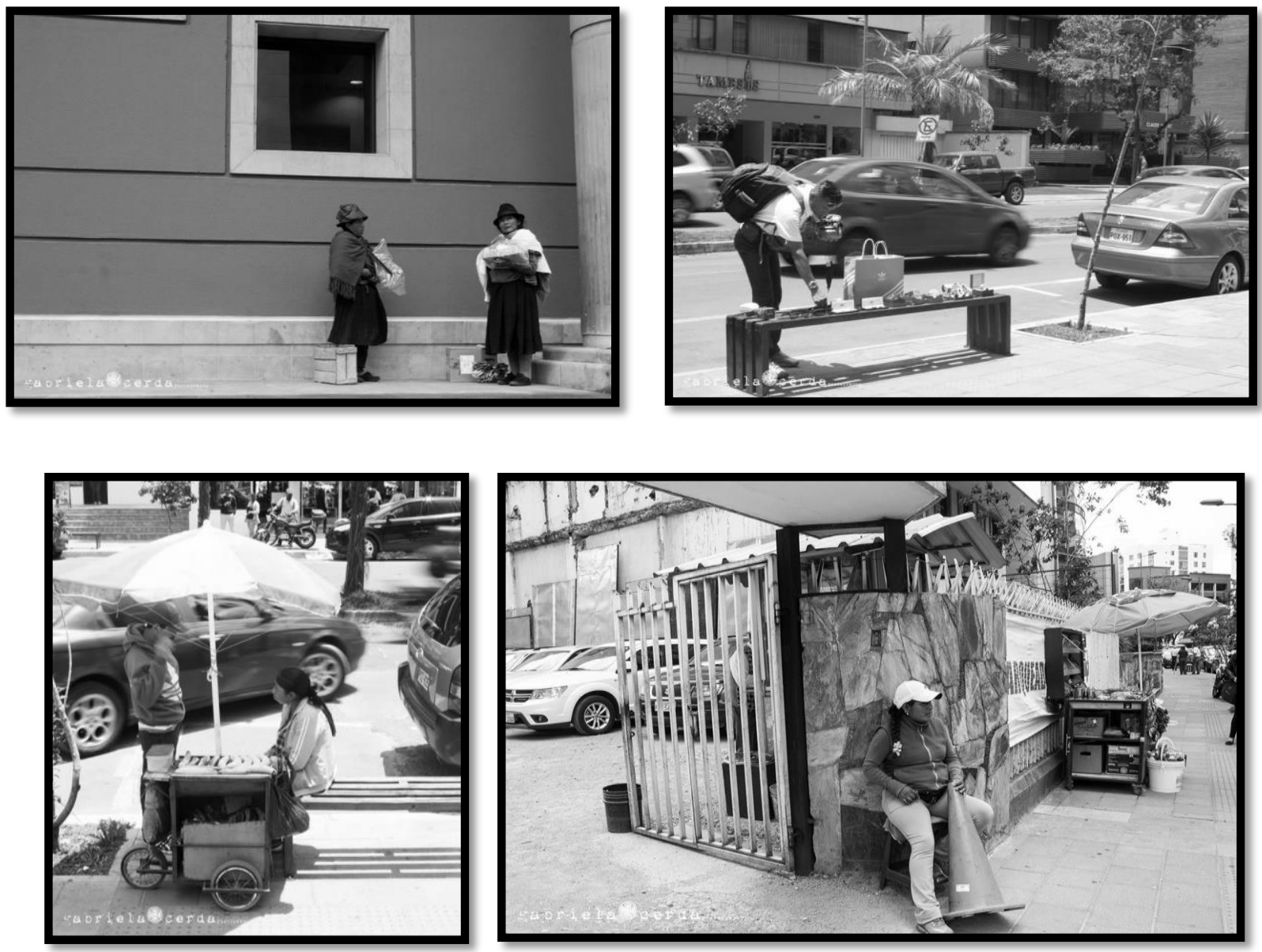

Figure 6: Photographs of informal merchants on the streets in Quito Photographer: Gabriela Cerda Trocellier

\section{Conclusions}

Summarizing, the last decade, the Ecuadorian policies, indeed has improved the general economic indicators, there has been growth in the GDP, the unemployment rates have been decreased, and there has been a significant transition of workers in the informal sector to the formal. However, there was a price that such implementations had, like a rise in the public and private debt numbers, a massive incensement in the tax charge, and the sacrifices that the workers in private sectors has been imposed to maintain the public sector. Such as receiving less annually income due to the reforms in the labour code. In this case of studying the informal sector of Ecuador, shows a clearly relation between the transition of informal sector to formal and the incensement of taxes and debt. Which in other terms could be seemed as a socialist policy which part of the population has to resign to some privileges to some provide labour security to others.

This system has been sustainable in this years, regarded mainly to the high prices of oil. There is a problem to depend an entire economy in one resource which creates a very sensitive bubble that at some point could no longer be sustainable. Besides the fact that debts should be paid at a certain date. The solution to eradicate the informality and the tax evasion, is not only to 
provide jobs, but to create productive jobs that are able to contribute to the development of the country. In this case the government is creating a public sector so vast that in longer term could produce a crash the economy. In other words, the Ecuadorian remedy to fight against the informality could be most expensive at the end than to live whit the informality disease.

\section{Bibliography}

Banco Central del Ecuador. (2014). Estadisticas Macroeconomicas. Quito: Banco Central del Ecuador.

Becker, M. (2011). Correa, Indigenous Movements, and the Writing of a New Constitution in Ecuador. Latin American Perspectives , 47-62.

Constante, S. (2014). Ecuador sumará 7.000 millones de dólares a su deuda con China. El Pais.

Económica, M. C. (2012). Indicadores Macroeconómicos. Ministerio Coordinador de la Política Económica.

Flores, L. (16 de march de 2014). Pequeños negocios familiares tributarán en nuevo régimen. El Economista.

Floro, M., \& Bali, S. (2013). Food Security, Gender, and Occupational Choice among Urban LowIncome Households. World Development, February, v. 42, iss. 1, pp. , 42(1), 89-99.

FORLAC. (2013). In Latin America there are 140 millon of informal workers. Lima: ILO.

Hart, K. (1973). Informal Income Opportunities and Urban Employment in Ghana. The Journal of Modern African Studies 1973, 61-89.

Inec. (2014). Indicadores laborales. Quito: Inec.

Jaramillo-Jassir, M. (2012). Populism and democratic consolidation during Rafael Correa's administration. Is it possible to ensure democracy through populism? Reflexión Politica, 142-153.

Lubel, H. (1993). The Informal Sector in Southeast Asia. Washington DC: US. Department of labour.

Neuwirth, R. (2012). Stealth of nations. Harlow : Anchor.

Ofice, I. L. (2002). Resolution concerning decent work and the informal economy . Geneva : GB.285/7/2.

Pallares, M. (21 de august de 2012). Petróleo para China hasta el 2016. El COMERCIO .

Portes, A., Castells, M., \& Benton, L. (1989). The Informal Economy: Studies in Advanced and Less Developed Countries. New York: Johns Hopkins University Press. 
Schneider, F., \& Klinglmair, R. (2004). Shadow Economies around the World: What Do We Know. IZA-Discussion Paper.

Serrano, A. (2012). Análisis De Informalidad En Ecuador. Fiscalidad.

Uquillas, C. (2007). "El outsourcing en el Ecuador" . Observatorio de la Economía Latinoamericana. 